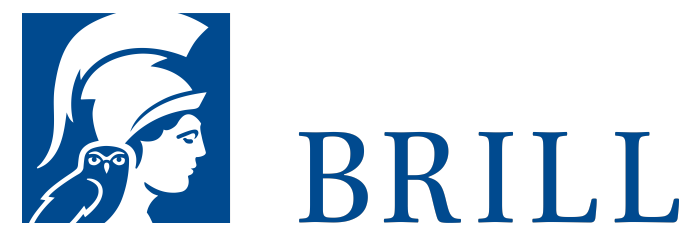

\title{
Der Neue Mann?
}

Männerporträts von Otto Dix, Christian Schad und Anton Räderscheidt 1914-1930

Author: Änne Söll

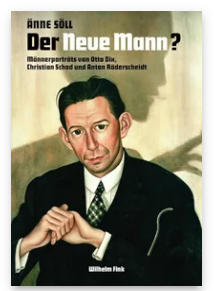

Wie sieht die Situation für Männer nach dem Ersten Weltkrieg in der Weimarer Republik aus? Welche Möglichkeiten der Repräsentation von Männlichkeit ergeben sich daraus? Anhand der Porträtmalerei von Christian Schad, Anton Räderscheidt und Otto Dix geht es um Männlichkeitsentwürfe der 1920er Jahre, deren Beziehung zum Bild der modernen Frau und ihrer medialen Repräsentation. Es werden die visuellen Strategien aufgezeigt, durch die sich moderne Männlichkeit zur Zeit der Weimarer Republik wieder legitimieren und stabilisieren konnte. Die Arbeit leistet damit einen entscheidenden Beitrag zur kulturwissenschaftlich orientierten Aufarbeitung der Kunst- und Geschlechtergeschichte der Weimarer Republik und beleuchtet den Anteil der neusachlichen Porträtmalerei an der Konstruktion damaliger Geschlechterbilder.

Pages: 320

Seiten, $72 \mathrm{~s} / \mathrm{w}$ und 36 farb. Abb.

Language:

German

Subjects: Art

History, Art

History

Publisher: Brill |

Fink

E-Book (PDF)

Released online:

29Jan 2020

ISBN: $978-3^{-}$

$8467-5861-8$

List price

Hardback

Publication date: o2 Dec 2016

ISBN: 978-37705-5861-2 List price 
Änne Söll ist zur Zeit Vertretungsprofessorin am Kunstgeschichtlichen Institut der Ruhr Universität Bochum. Forschungsschwerpunkte sind die Kunst des 20. und 21. Jahrhunderts mit dem Fokus auf Geschlechterthemen, Affektforschung, Mode, Zeitschriften, Videokunst und Fotografie. Ihre Dissertation zum Thema Körper in den Arbeiten von Pipilotti Rist ist 2004 erschienen.

For more information see brill.com

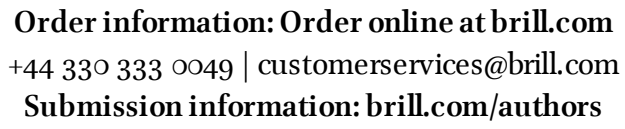

